\title{
Effects of Exercise on Low Density Lipoprotein Receptor Related Protein 5 Gene Expression in Patients With Postmenopausal Osteoporosis
}

\author{
Gamze KILIÇ, ${ }^{1}$ Didem DAYANGAÇ ERDEN, ${ }^{2}$ Özlem EROL, ${ }^{1}$ Erkan KILIÇ, \\ Murat KARA, ${ }^{1}$ Hayat ERDEM YURTER, ${ }^{2}$ Ayşen AKINCI ${ }^{1}$ \\ ${ }^{1}$ Department of Physical Medicine and Rehabilitation, Medical Faculty of Hacettepe University, Ankara, Turkey \\ ${ }^{2}$ Department of Medical Biology, Medical Faculty of Hacettepe University, Ankara, Turkey
}

\begin{abstract}
Objectives: This study aims to investigate the effects of aerobic exercise on low density lipoprotein receptor related protein 5 (LRP5) gene messenger ribonucleic acid expression and evaluate the relationship between the clinical parameters and gene expression in patients with postmenopausal osteoporosis (OP).

Patients and methods: Seven patients with postmenopausal OP (mean age $60.0 \pm 5.3$ years; range 51 to 66 years) were included in the study. An exercise protocol/program consisting of treadmill exercising for 30 minutes three days a week for six weeks was performed at a moderate intensity. LRP5 gene expression levels were evaluated before the onset of the exercise program and then four hours after the end of the first session and $12^{\text {th }}$ (fourth week) and $18^{\text {th }}$ (sixth week) sessions of exercise.

Results: Our results demonstrated variable changes in the LRP5 gene expression after the aerobic exercise sessions. Excluding one patient, the LRP5 gene expression levels showed a slight tendency to increase. In spite of this tendency, gene expression differences during the exercise sessions were not significant.

Conclusion: Our results suggest that interindividual variations of LRP5 gene expression exist after moderate intensity aerobic exercises in patients with postmenopausal OP. Despite of this variability, LRP5 gene expression levels increased slightly, except in peripheral blood in one patient. Future studies with larger sample sizes and different sampling time/tissues are required to shed more light on the impact of exercise at molecular level in OP. Keywords: Exercise; lipoprotein receptor related protein 5; messenger ribonucleic acid expression; osteoporosis.
\end{abstract}

Osteoporosis (OP) is a common metabolic bone disease which is characterized by decreased bone mass and deterioration in the microarchitecture of the bone tissue, leading to an increased fracture risk. The etiology of OP includes both genetic and environmental factors. Genetic factors have an important role in the regulation of the bone mineral density (BMD) and contribute to $80 \%$ of the variation in BMD among individuals. ${ }^{1,2}$ Many determinants of the osteoporotic fracture risk are heritable, such as body mass index, hip axis length, femoral neck geometry, biochemical markers of bone turnover, muscle strength, peak bone mass, menarche, and menopause status. ${ }^{3-11}$

Environmental factors, under the influence of the genetic variations, play a significant role in the pathogenesis of OP; yet the contribution of this interaction remains poorly understood. Among the environmental factors, physical exercise is a well-known determinant in attaining and keeping the peak bone mass. Exercise has generally been considered to have a positive effect on the bones and thus to be useful in the treatment of OP. Likewise, physical activity as a way of preventing 
$\mathrm{OP}$ is based on the evidence that it helps bone maintenance and stimulation of bone formation including mineralization; strengthens muscles, improves balance and postural control. Exercise also increases fitness and quality of life, decreases pain intensity, fracture risk, and prevents agerelated decline in the levels of vitamin D. ${ }^{12-15}$

Several studies suggested that genetic variations may modify the effects of intensive physical training on the musculoskeletal system. ${ }^{16-18}$ Among these genetic variations, lipoprotein receptor related protein 5 (LRP5) variants have been found to influence the effects of physical activity on spine bone density in males and Wnt signaling in vitro. ${ }^{16}$

The Wnt signaling pathway including LRP5 and Wnt proteins regulate osteoblastic activity and bones mass. ${ }^{19}$ This pathway promotes proliferation and mineralization in osteoblasts and inhibits osteoclastogenesis by increasing the osteoprotegerin/receptor activator of receptor activator of NFKB ligand (RANKL) ratio.

The LRP5 gene harbors naturally occurring coding polymorphisms which have been proposed to contribute to the normal population variance in bone metabolism. ${ }^{20-22}$ Also, mutations in the LRP5 gene have been shown to result in various single gene disorders with either a high or low BMD phenotype. ${ }^{20,23}$ Polymorphisms and mutations in the LRP5 gene have been studied in several populations and countries. ${ }^{16,20,24,25}$ Some of those studies have showed a modulatory effect of different LRP5 alleles on the Wnt signaling as well as on the association between BMD and physical activity. However, to the best of our knowledge, the effects of exercise on LRP5 gene expression have not been reported in the literature. Therefore, in this study, we aimed to investigate the effects of aerobic exercise on LRP5 gene messenger ribonucleic acid expression and evaluate the relationship between the clinical parameters and gene expression in patients with postmenopausal OP.

\section{PATIENTS AND METHODS}

A total of seven untrained patients with postmenopausal OP (mean age 60.0 \pm 5.3 years; range 51 to 66 years) were included from outpatient clinic of department of physical medicine and rehabilitation, Hacettepe University. Patients who had cardiac, neurological or orthopedic disorders which may cause difficulty in walking or those using any medication known to affect the bone metabolism were excluded. Demographic characteristics of the patients and their risk factors for OP including body mass index, alcohol and cigarette usage, daily activity level and exercise habits, immobilization and fracture history, family history of bone disease, style of clothing, daily length of stay in the sun light, calcium intake, medications, and concomitant diseases were also recorded. The study protocol was approved by the local Ethics Committee of Hacettepe University and written informed consents were obtained from all subjects. The study was conducted in accordance with the principles of the Declaration of Helsinki.

Serum levels of calcium, phosphate, osteocalcin, bone specific alkaline phosphatase, carboxyterminal telopeptide of type I collagen, parathyroid hormone, 25-hydroxy vitamin $\mathrm{D}_{3}$ $\left(25(\mathrm{OH}) \mathrm{D}_{3}\right)$, complete blood count, erythrocyte sedimentation rate, C-reactive protein, liver/renal function tests, thyroid-stimulating hormone, and free $\mathrm{T}_{4}$ were measured.

Radiographies of the pelvis, thoracic and lumbar spine were taken. Bone mineral content and BMD of the spine (L2-L4) and the hip were measured by dual energy X-ray absorptiometry using Hologic QDR 4500 densitometer (Hologic, Inc., Bedford, MA).

The exercise protocol consisted of treadmill training at a moderate intensity for 30 minutes three days a week for six weeks under direct supervision. Exercises started after a warm-up period and ended with stretching exercises lasting five to 10 minutes. Exercises were performed at a moderate intensity as followed by the target heart rate which has been determined according to the Karvonen method. ${ }^{26}$

Blood samples were collected into PAXgene Blood RNA Tube (QIAGEN GmbH, Hilden, Germany) for LRP5 gene expression evaluations. The first sample was taken after an eight-hour overnight fasting period. The follow-up samples were drawn four hours following the end of the first, $12^{\text {th }}$ and $18^{\text {th }}$ sessions of exercise. Twentyfour hours prior to the test sessions, subjects 
consumed a standard diet and abstained from alcohol and caffeine consumption as well as strenuous exercise.

Total ribonucleic acid was isolated using PAXgene Blood RNA Kit (QIAGEN $\mathrm{GmbH}$, Hilden, Germany) protocol and reagents. ${ }^{27,28}$ Complementary deoxyribonucleic acid was synthesized using Quantitect Reverse Transcription Kit (QIAGEN GmbH, Hilden, Germany) as described by the manufacturer. After reverse transcription, the SYBR Green based quantitative real-time polymerase chain reaction was performed using the BioradiCycler IQ5 real-time Detection System (Applied Biosystems). LRP5 complementary deoxyribonucleic acids were run simultaneously and in triplicate. LRP5 gene expression was normalized to beta-actin and TATA-binding protein housekeeping genes. Fluorescent emission data were captured and messenger ribonucleic acid levels were quantified by comparative $\mathrm{Ct}$ method. ${ }^{29}$

\section{Statistical analysis}

Statistical analysis was performed using SPSS for Windows version 16.0 software (SPSS Inc., Chicago, IL, USA). Friedman test was used for the analysis of gene expression level measurements. Pearson correlation analysis was used for the assessment of relationship between parameters. Data are expressed as median \pm standard deviation. Statistical significance was set at $\mathrm{p}<0.05$.

\section{RESULTS}

Patients 5 and 7 were smokers, but none of them were using alcohol. Laboratory test results are given in Table 1. Patients 5, 6 and 7 had 25(OH)D levels below $20 \mu \mathrm{g} / \mathrm{L}$ while five patients' serum bone specific alkaline phosphatase levels were above the reference values (12.5-22.4 ug/L) for our center. Otherwise, all patients' test results were normal. BMD of the patients are given in Table 2.

Total ribonucleic acid concentration was determined spectrophotometrically at 143-149 $\mathrm{ng} / \mathrm{uL}$. Individual changes in LRP5 gene expression levels after the aerobic exercise sessions are shown in Figure 1. Excluding patient 4, LRP5 gene expressions showed a slight tendency to increase. However, this increase was not statistically significant. The differences between LRP5 gene expression levels in seven patients after each aerobic exercise session are given in Figure 2.

Table 1. Laboratory test results of patients

\begin{tabular}{|c|c|c|c|c|c|c|c|}
\hline & Patient 1 & Patient 2 & Patient 3 & Patient 4 & Patient 5 & Patient 6 & Patient 7 \\
\hline White blood cell $(/ \mu \mathrm{L})$ & 4900 & 5900 & 5400 & 3700 & 6200 & 3700 & 6000 \\
\hline Hemoglobin $(\mathrm{g} / \mathrm{dL})$ & 13.6 & 13.6 & 13.9 & 12.8 & 12.4 & 13.4 & 13 \\
\hline Hematocrit (\%) & 39.7 & 41.2 & 41.5 & 36.9 & 36.8 & 39.4 & 38.9 \\
\hline Platelet $(/ \mu \mathrm{L})$ & 324000 & 219000 & 256000 & 149000 & 303000 & 197000 & 222000 \\
\hline Erythrocyte sedimentation rate $(\mathrm{mm} / \mathrm{h})$ & 10 & 5 & 11 & 11 & 38 & 13 & 11 \\
\hline C-reactive protein (mg/dL) & 0.21 & 0.37 & 0.19 & 0.27 & 0.8 & 0.17 & 0.17 \\
\hline Blood urea nitrogen $(\mathrm{mg} / \mathrm{dL})$ & 19.9 & 13 & 18 & 17 & 16 & 12 & 21 \\
\hline Creatinin (mg/dL) & 0.74 & 0.8 & 0.58 & 0.8 & 0.7 & 0.91 & 0.86 \\
\hline Calsium (mg/dL) & 9.27 & 9.2 & 9.4 & 8.9 & 8.8 & 9.5 & 8.9 \\
\hline Phosphate (mg/dL) & 3.43 & 4.2 & 3.49 & 4.32 & 3.2 & 3.93 & 4.92 \\
\hline Albumin (g/dL) & 4.58 & 4.4 & 4.61 & 3.9 & 4.3 & 4.27 & 4 \\
\hline Aspartate aminotransferase (U/L) & 23 & 16 & 14 & 18 & 16 & 20 & 22 \\
\hline Alanine aminotransferase (U/L) & 19 & 11 & 22 & 15 & 15 & 15 & 23 \\
\hline Alkaline phosphatase (U/L) & 72 & 77 & 69 & 75 & 78 & 75 & 38 \\
\hline $\mathrm{sT}_{3}(\mathrm{pmol} / \mathrm{L})$ & 3.92 & 4.74 & 4.62 & 6.2 & 4.9 & 4.44 & 6.03 \\
\hline $\mathrm{sT}_{4}(\mathrm{pmol} / \mathrm{L})$ & 14.23 & 14.99 & 15.97 & 19.8 & 13.7 & 13.37 & 14.92 \\
\hline Thyroid-stimulating hormone (uIU/mL) & 0.76 & 2.15 & 1.76 & 2.44 & 1.8 & 2.35 & 2.22 \\
\hline Parathyroid hormone (pg/mL) & 41.4 & 36.2 & 30.6 & 18.1 & 106 & 50.1 & 101 \\
\hline 25-hydroxy vitamin D3 ( $\mu \mathrm{g} / \mathrm{L})$ & 20.2 & 23.2 & 42.2 & 44.7 & 7.4 & 13.8 & 16.6 \\
\hline Osteocalsin $(\mathrm{ng} / \mathrm{mL})$ & 30.12 & 25.55 & 29.86 & 19.31 & 15.7 & 29.02 & 14.37 \\
\hline Bone specific alkaline phosphatase (ug/L) & 32 & 28.4 & 41.8 & 29.6 & 20.1 & 33.5 & 13.2 \\
\hline $\begin{array}{l}\text { Carboxyterminal telopeptide of } \\
\text { type I collagen (ng/mL) }\end{array}$ & 0.55 & 0.24 & 0.68 & 0.56 & 0.39 & 0.45 & 0.15 \\
\hline
\end{tabular}




\begin{tabular}{|c|c|c|c|c|c|c|c|}
\hline & Patient 1 & Patient 2 & Patient 3 & Patient 4 & Patient 5 & Patient 6 & Patient 7 \\
\hline \multicolumn{8}{|l|}{ T score } \\
\hline $\mathrm{L}_{1-4}$ & -2.8 & -2.4 & -2.9 & -2.5 & -3.3 & -2.3 & -3.4 \\
\hline Femoral neck & -2.0 & -2.2 & -1.9 & -1.9 & -1.5 & -1.1 & -2.0 \\
\hline Total hip & -1.8 & -2.8 & -1.8 & -1.2 & -1 & -0.4 & -1.4 \\
\hline \multicolumn{8}{|c|}{ Bone mineral density $\left(\mathrm{g} / \mathrm{cm}^{2}\right)$} \\
\hline $\mathrm{L}_{1-4}$ & 0.89 & 0.9 & 0.84 & 0.89 & 0.78 & 0.91 & 0.78 \\
\hline Femoral neck & 0.81 & 0.73 & 0.77 & 0.78 & 0.83 & 0.88 & 0.76 \\
\hline Total hip & 0.85 & 0.66 & 0.78 & 0.86 & 0.89 & 0.96 & 0.83 \\
\hline
\end{tabular}

\section{DISCUSSION}

To the best of our knowledge, this is the first study assessing the effects of exercise on LRP5 gene expression in patients with postmenopausal OP. Our results suggest that interindividual variations of LRP5 gene expression occur after moderate intensity aerobic exercises in this group of patients. Nonetheless, LRP5 gene expression levels showed a slight increase, except for one patient.

Low BMD comprises the major risk for fractures that cause significant morbidity and mortality in patients with OP. Longitudinal studies on families and twins suggest that variation in BMD is strongly influenced by genes; ${ }^{1}$ however, the exact nature of the genes governing BMD variation remains poorly understood. To date, the effects of different genes (vitamin D, aromatase, sex hormone receptors etc.) and their variations have been widely studied.5,30 Lately, the Wnt signaling pathway including the LRP5 and Wnt proteins has been discovered as an important pathway regulating the osteoblastic activity and thereby bone mass. Moreover, mutations in the LRP5 gene have been demonstrated to cause different single gene disorders resulting in either increased or decreased BMD. ${ }^{20}$ Besides these mutations, coding polymorphisms in the LRP5 gene have been suggested to contribute to the normal population variance in bone metabolism. The association between various polymorphisms in LRP5 gene and peak bone mass has been investigated in different populations. ${ }^{20,21,31}$ A significant association between physical activity and polymorphisms in the LRP5 gene has been discovered through these studies. ${ }^{16,32}$ LRP5 gene seems to affect the adaptive response of bone to mechanical loading and may also play role in the regulation of bone metabolism. ${ }^{33}$

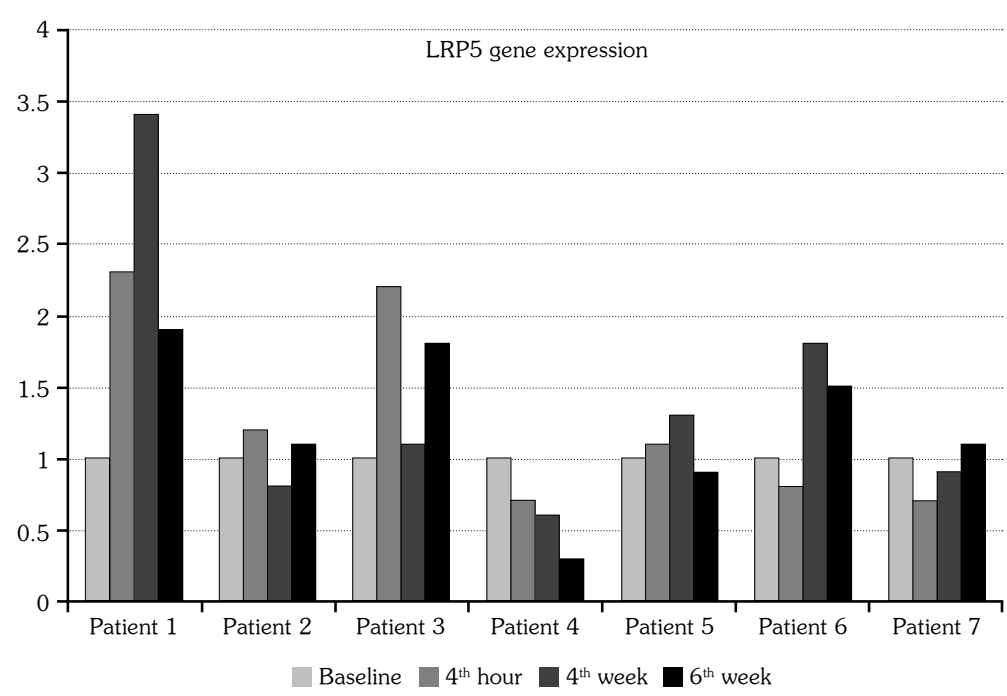

Figure 1. Individual changes in low density lipoprotein receptor related protein 5 (LRP5) gene expression levels after aerobic exercise sessions. 


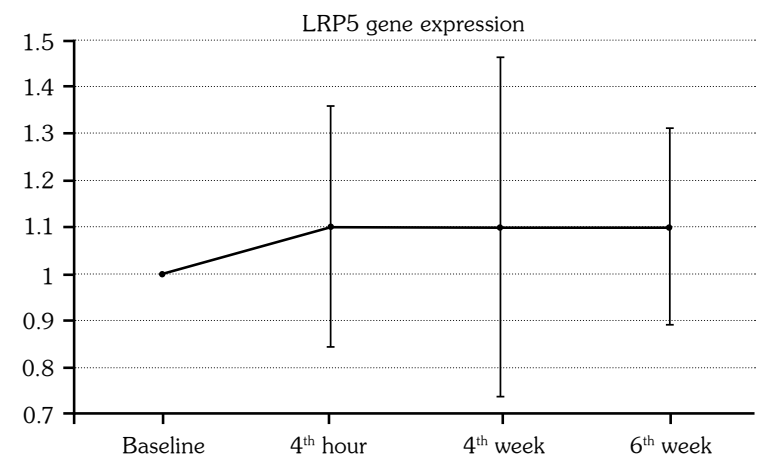

Figure 2. Differences between low density lipoprotein receptor related protein 5 (LRP5) gene expression levels after each aerobic exercise session.

The regulation of human LRP5 gene expression is still not known. Li et al. ${ }^{34}$ cloned the human LRP5 promoter and analyzed its transcriptional regulation and demonstrated that both specificity protein 1 and Krüppel-like factor 15 motifs were essential for human LRP5 promoter activity. It has been demonstrated that the expression of LRP5 in osteoblast was increased by bone morphogenetic protein $2 .{ }^{35}$ Fretz et al. ${ }^{36}$ discovered that $1,25(\mathrm{OH})_{2} \mathrm{D}_{3}$ may induce binding of the vitamin D receptor to sites within the LRP5 gene locus. This interaction is thought to cause a modification in chromatin structure within the LRP5 locus and induce LRP5 messenger ribonucleic acid transcription in osteoblasts. They also suggested that the contributory effect of this up-regulation of LRP 5 by $1,25(\mathrm{OH})_{2} \mathrm{D}_{3}$ to the overall actions of $1,25(\mathrm{OH})_{2} \mathrm{D}_{3}$ on bone remained to be determined. ${ }^{35}$ Actually, if there is such an interaction between vitamin D and LRP5 gene expression, this might have at least partially played some part in the variation of our patients' LRP5 expression patterns.

Whether exercise has an influence on LRP5 gene expression is still unclear. There are several studies about the regulatory effect of exercise on various myogenic and metabolic gene expressions. ${ }^{37,38}$ Mode of exercise, timing of sampling, type of the gene studied, host factors like feeding status, age, sex, and activity level are all important variables that might influence the gene induction response to exercise in humans. Yang et al. ${ }^{38}$ studied the time course of myogenic and metabolic gene expression in response to acute exercise in human skeletal muscle and suggested that timing of the gene induction was variable and that it showed a peak four to eight hours after exercise. Likewise, we took our samples four hours following the exercise sessions. Although the effect of exercise on gene expression has usually been investigated on muscle biopsy sections, Buttner et al. ${ }^{39}$ showed that white blood cells are a useful source to analyze gene expression after exercise. So, in this study, we decided that peripheral blood sampling would be efficient and acceptable.

In conclusion, our study provides preliminary clues about the effects of exercise on LRP5 gene expression levels. The results of our study demonstrated a slight increase in LRP5 gene expressions after exercise sessions in all patients, except one patient. The reason for this discrepancy may be due to genetic background among individuals. Therefore, analyzing LRP5 gene polymorphisms may help to establish a correlation between LRP5 genotypes and LRP5 expression levels. Future studies with larger sample sizes and different sampling time/tissues are required to shed more light on the impact of exercise (at molecular level) in OP.

\section{Declaration of conflicting interests}

The authors declared no conflicts of interest with respect to the authorship and/or publication of this article.

\section{Funding}

This study was supported by Hacettepe University Scientific Research Unit (project no: 010D06101002).

\section{REFERENCES}

1. Brown LB, Streeten EA, Shuldiner AR, Almasy LA, Peyser PA, Mitchell BD. Assessment of sex-specific genetic and environmental effects on bone mineral density. Genet Epidemiol 2004;27:153-61.

2. Karasik D, Ferrari SL. Contribution of gender-specific genetic factors to osteoporosis risk. Ann Hum Genet 2008;72:696-714.

3. Arden NK, Baker J, Hogg C, Baan K, Spector TD. The heritability of bone mineral density, ultrasound of the calcaneus and hip axis length: a study of postmenopausal twins. J Bone Miner Res 1996;11:530-4.

4. Slemenda CW, Turner $\mathrm{CH}$, Peacock M, Christian JC, Sorbel J, Hui SL, et al. The genetics of proximal femur geometry, distribution of bone mass and bone mineral density. Osteoporos Int 1996;6:178-82. 
5. Albagha OM, Pettersson U, Stewart A, McGuigan FE, MacDonald HM, Reid DM, et al. Association of oestrogen receptor alpha gene polymorphisms with postmenopausal bone loss, bone mass, and quantitative ultrasound properties of bone. $\mathrm{J}$ Med Genet 2005;42:240-6.

6. Morrison NA, Yeoman R, Kelly PJ, Eisman JA. Contribution of trans-acting factor alleles to normal physiological variability: vitamin $\mathrm{D}$ receptor gene polymorphism and circulating osteocalcin. Proc Natl Acad Sci U S A 1992;89:6665-9.

7. Hunter $\mathrm{D}$, De Lange $\mathrm{M}$, Snieder $\mathrm{H}$, MacGregor AJ, Swaminathan R, Thakker RV, et al. Genetic contribution to bone metabolism, calcium excretion, and vitamin $\mathrm{D}$ and parathyroid hormone regulation. $\mathrm{J}$ Bone Miner Res 2001;16:371-8.

8. Arden NK, Spector TD. Genetic influences on muscle strength, lean body mass, and bone mineral density: a twin study. J Bone Miner Res 1997;12:2076-81.

9. Kaprio J, Rimpelä A, Winter T, Viken RJ, Rimpelä M, Rose RJ. Common genetic influences on BMI and age at menarche. Hum Biol 1995;67:739-53.

10. Snieder H, MacGregor AJ, Spector TD. Genes control the cessation of a woman's reproductive life: a twin study of hysterectomy and age at menopause. J Clin Endocrinol Metab 1998;83:1875-80.

11. Blades HZ, Arundel P, Carlino WA, Dalton A, Crook JS, Freeman JV, et al. Collagen gene polymorphisms influence fracture risk and bone mass acquisition during childhood and adolescent growth. Bone 2010;47:989-94.

12. Feskanich D, Willett W, Colditz G. Walking and leisure-time activity and risk of hip fracture in postmenopausal women. JAMA 2002;288:2300-6.

13. Kemmler $\mathrm{W}$, Engelke $\mathrm{K}$, Weineck $\mathrm{J}$, Hensen $\mathrm{J}$, Kalender WA. The Erlangen Fitness Osteoporosis Prevention Study: a controlled exercise trial in early postmenopausal women with low bone density-firstyear results. Arch Phys Med Rehabil 2003;84:673-82.

14. Scragg R, Camargo CA Jr. Frequency of leisure-time physical activity and serum 25-hydroxyvitamin D levels in the US population: results from the Third National Health and Nutrition Examination Survey. Am J Epidemiol 2008;168:577-86.

15. Schmitt NM, Schmitt J, Dören M. The role of physical activity in the prevention of osteoporosis in postmenopausal women-An update. Maturitas 2009;63:34-8.

16. Kiel DP, Ferrari SL, Cupples LA, Karasik D, Manen $\mathrm{D}$, Imamovic $\mathrm{A}$, et al. Genetic variation at the lowdensity lipoprotein receptor-related protein 5 (LRP5) locus modulates Wnt signaling and the relationship of physical activity with bone mineral density in men. Bone 2007;40:587-96.

17. Lang DH, Conroy DE, Lionikas A, Mack HA, Larsson L, Vogler GP, et al. Bone, muscle, and physical activity: structural equation modeling of relationships and genetic influence with age. $\mathrm{J}$ Bone Miner Res
2009;24:1608-17.

18. McCauley T, Mastana SS, Hossack J, Macdonald M, Folland JP. Human angiotensin-converting enzyme I/D and alpha-actinin 3 R577X genotypes and muscle functional and contractile properties. Exp Physiol 2009;94:81-9.

19. Gong Y, Slee RB, Fukai N, Rawadi G, Roman-Roman $\mathrm{S}$, Reginato AM, et al. LDL receptor-related protein 5 (LRP5) affects bone accrual and eye development. Cell 2001;107:513-23.

20. Ferrari SL, Deutsch S, Antonarakis SE. Pathogenic mutations and polymorphisms in the lipoprotein receptor-related protein 5 reveal a new biological pathway for the control of bone mass. Curr Opin Lipidol 2005;16:207-14.

21. Koay MA, Woon PY, Zhang Y, Miles LJ, Duncan EL, Ralston SH, et al. Influence of LRP5 polymorphisms on normal variation in BMD. J Bone Miner Res 2004;19:1619-27.

22. van Meurs JB, Trikalinos TA, Ralston SH, Balcells S, Brandi ML, Brixen K, et al. Large-scale analysis of association between LRP5 and LRP6 variants and osteoporosis. JAMA 2008;299:1277-90.

23. Levasseur R, Lacombe D, de Vernejoul MC. LRP5 mutations in osteoporosis-pseudoglioma syndrome and high-bone-mass disorders. Joint Bone Spine 2005;72:207-14.

24. Zhang ZL, Qin YJ, He JW, Huang QR, Li M, Hu YQ, et al. Association of polymorphisms in low-density lipoprotein receptor-related protein 5 gene with bone mineral density in postmenopausal Chinese women. Acta Pharmacol Sin 2005;26:1111-6.

25. Tran BN, Nguyen ND, Eisman JA, Nguyen TV. Association between LRP5 polymorphism and bone mineral density: a Bayesian meta-analysis. BMC Med Genet 2008;9:55.

26. Karvonen MJ, Kentala E, Mustala O. The effects of training on heart rate; a longitudinal study. Ann Med Exp Biol Fenn 1957;35:307-15.

27. Chai V, Vassilakos A, Lee Y, Wright JA, Young AH. Optimization of the PAXgene blood RNA extraction system for gene expression analysis of clinical samples. J Clin Lab Anal 2005;19:182-8.

28. Debey-Pascher S, Eggle D, Schultze JL. RNA stabilization of peripheral blood and profiling by bead chip analysis. Methods Mol Biol 2009;496:175-210.

29. Schmittgen TD, Zakrajsek BA, Mills AG, Gorn $\mathrm{V}$, Singer MJ, Reed MW. Quantitative reverse transcription-polymerase chain reaction to study mRNA decay: comparison of endpoint and real-time methods. Anal Biochem 2000;285:194-204.

30. Jia F, Sun RF, Li QH, Wang DX, Zhao F, Li JM, et al.Vitamin D receptor BsmI polymorphism and osteoporosis risk: a meta-analysis from 26 studies. Genet Test Mol Biomarkers 2013;17:30-4.

31. Bollerslev J, Wilson SG, Dick IM, Islam FM, Ueland $\mathrm{T}$, Palmer L, et al. LRP5 gene polymorphisms predict 
bone mass and incident fractures in elderly Australian women. Bone 2005;36:599-606.

32. Brixen K, Beckers S, Peeters A, Piters E, Balemans $\mathrm{W}$, Nielsen TL, et al. Polymorphisms in the lowdensity lipoprotein receptor-related protein 5 (LRP5) gene are associated with peak bone mass in nonsedentary men: results from the Odense androgen study. Calcif Tissue Int 2007;81:421-9.

33. Akhter MP, Wells DJ, Short SJ, Cullen DM, Johnson ML, Haynatzki GR, et al. Bone biomechanical properties in LRP5 mutant mice. Bone 2004;35:162-9.

34. Li J, Yang Y, Jiang B, Zhang X, Zou Y, Gong Y. Sp1 and KLF15 regulate basal transcription of the human LRP5 gene. BMC Genet 2010;11:12.

35. Zhang M, Yan Y, Lim YB, Tang D, Xie R, Chen A, et al. BMP-2 modulates beta-catenin signaling through stimulation of Lrp5 expression and inhibition of beta-TrCP expression in osteoblasts. $\mathrm{J}$ Cell Biochem 2009;108:896-905.
36. Fretz JA, Zella LA, Kim S, Shevde NK, Pike JW. 1,25-Dihydroxyvitamin D3 regulates the expression of low-density lipoprotein receptor-related protein 5 via deoxyribonucleic acid sequence elements located downstream of the start site of transcription. Mol Endocrinol 2006;20:2215-30.

37. Tunstall RJ, Mehan KA, Wadley GD, Collier GR, Bonen A, Hargreaves $M$, et al. Exercise training increases lipid metabolism gene expression in human skeletal muscle. Am J Physiol Endocrinol Metab 2002;283:66-72.

38. Yang Y, Creer A, Jemiolo B, Trappe S. Time course of myogenic and metabolic gene expression in response to acute exercise in human skeletal muscle. J Appl Physiol (1985) 2005;98:1745-52.

39. Büttner $\mathrm{P}$, Mosig S, Lechtermann A, Funke $\mathrm{H}$, Mooren FC. Exercise affects the gene expression profiles of human white blood cells. J Appl Physiol (1985) 2007;102:26-36. 